\title{
Two Publications, One Message
}

\author{
Ferdinand Trauttmansdorff / ftrautt@hotmail.com
}

Former diplomat, expert on international law and international relations, Ambassador Emeritus of the Republic of Austria to the Czech Republic Andrássy University Budapest, Chair of Diplomacy

\begin{abstract}
In a lecture given at the Faculty of Arts of Masaryk University in Brno as part of the "Days of Liechtenstein History in the Czech Republic" event, former Ambassador of the Republic of Austria to the Czech Republic Ferdinand Trauttmannsdorff presented two projects by the Czech-Liechtenstein Commission of Historians. The first concerns the publication of „Fürstenhaus Liechtenstein - Böhmische Länder - Fürstentum Liechtenstein. Ad honorem Thomas Winkelbauer", which was published in the Studia Historica Brunensia journal. Authors from the Czech-Liechtenstein Commission of Historians have published a series of articles dealing with various aspects of the history of the Liechtenstein family and their ties to the Czech Lands, the history of the Principality of Liechtenstein, as well as with some more general topics from European history. The second topic presented was the publication of an English language version of the commission's "Summary Report of the Czech-Liechtenstein Commission of Historians", entitled "Czech-Liechtenstein Relations. Past and Present". The author of the lecture emphasized in particular the passages devoted to the places of Liechtenstein's memory and the construction of various historical stereotypes typical of Czech-Liechtenstein relations over the long run. He also emphasized some of the chances that, in his opinion, an improvement in Czech-Liechtenstein relations and the resolution of issues still considered as unresolved could bring in the future not only to both countries involved, but also to Europe as a whole.
\end{abstract}

\section{Keywords}

Principality of Liechtenstein, Czech Lands, Czech Republic, Czech-Liechtenstein historians' Commission, Charles I. of Liechtenstein, Summary Report

Czech-Liechtenstein Commission of Historians, Days of History at the Masaryk-University in Brno. Intervention by Ferdinand Trauttmansdorff on November 20, 2019. 


\section{Ladies and Gentlemen,}

I am a rather recent member of the Czech-Liechtenstein historian's Commission and I am technically no historical scientist and no art historian either. That may seem at first sight to disqualify me from presenting two publications representing a high standard of historical research by reuniting contributions of extraordinary quality.

I would, however, not dare to stand here in front of you, if I would not feel, nevertheless, in a privileged position to shed a light on these two publications from the point of view of a diplomat and scholar of international law and international relations, who had a chance to develop an intensive as well as extensive insight into the changing context of historical, political, diplomatic and legal relations between the lands that, today, form the Czech Republic on the one hand and the principality as well as the family of Liechtenstein on the other. And I think I can recognize from my somewhat different standpoint messages attached to the two publications that reach out well beyond the historical research on which they are based and which they reflect.

The first publication has been organized by a team of the Masaryk University under Prof. Tomas Knoz in order to honour Professor Thomas Winkelbauer. Prof. Winkelbauer invested a large part of his outstanding historical research into Czech history and he also covered important aspects of the relations between the Liechtensteins and the Czech lands throughout nearly 8 centuries of common history. The book, published in honour of Tomas Winkelbauer, has been given the short but expressive title Fürstenhaus Liechtenstein - Böhmische Länder - Fürstentum Liechtenstein - i.e the house of Liechtenstein-the Czech Lands-the principality of Liechtenstein. The publication covers highly relevant aspects of the Liechtensteins and the Czech lands. Three articles by Thomas Knoz, Arthur Stögmann and Jiři Brňovják specially concentrate on the figure of Karl I. of Liechtenstein, who has been object of profound stereotypisation in the context of the consequences of the battle on the White Mountain and at the same time has become one of the decisive figures of the history of the Liechtensteins, not only as the first prince. Other contributions include Petr Eibel shedding light on the role of the Liechtensteins during the Hussite wars, Zdenka Stoklásková on factual freedom of former serfs (Leibeigene - nevolniky) after the abolition of serfdom taking the example of Liechtenstein possessions, Michal Konečny looking into building architecture and Vladimír Maňas on music at Liechtenstein courts. Ondřej Horák and Vacláv Horčička add contributions in their field of specialty, the issues of expropriation, confiscation and national administration applied to the Liechtenstein in the $20^{\text {th }}$ century. The content of this publication is further enriched by two articles by the former colleagues of the laureate in the Historian's Commission, Catherine Horel, who exposed a little known history of "Civil Croatia" and of Jan Županič, who dealt with the special history of Jewish aristocracy in Prussia. The book is rounded ab by an extensive Bibliography put together by Tomáš Knoz and Markéta Peřestá. All in all, this book honours Thomas Winkelbauer by reflecting the breadth and depth of his historical research, writing and teaching, which excel in exposing the wealth and variety of Central European history and the interdependence and structural interrelationships of national identities developed during the 
last two centuries. No wonder that with this broad focus of historical research, the role of the Liechtensteins was a natural subject to concentrate on for Thomas Winkelbauer.

The other publication we have long since been impatiently waiting for is the English version of the Summary report of the work of the Czech-Liechtenstein Commission of Historians, entitled Czech-Liechtenstein relations, past and present. Its text has now practically been finalized and will be published within the next weeks on the Website of the commission of historians as well as in printed form. All the eight members of the Commission in its former composition in 2014 contributed to this synthetic report. Of course the studies and research as well as opinions developed in 7 publications over more than 2000 pages are rather detailed and need quite extensive reading to gain an overview over the most important features of the Czech-Liechtenstein relationship over 800 years. In this regard this synthesis has become a particular success story. It succeeded indeed remarkably well in summarizing the most important findings of the Commission, while remaining sufficiently detailed in order to present the enormous wealth of insights that have the full potential of forming a new picture of the very special character of the Liechtenstein-Czech relations. The summary also lays open an overview of the activities of the Historian`s Commission and on the methods of work. In the Annex no less than 40 pages of sources and literature are listed, as well as a record of meetings and publications of the Commission. I think that this alone makes the results of the work of this Commission unique compared with other attempts trying to reconcile controversial and opposing historical narratives. The Summary Report reflects in condensed form the successful attempts of the commission to expose and redefine a whole wealth of historical truth that has been distorted beforehand by forcing bits and pieces of historical facts into misleading stereotypes. Such distorting stereotypes served in many cases as "crutches" to bolster efforts of re-branding the national identity of one country at the cost of others or, in turn, in order to permanently blame another country for injustices the wounds of which are never supposed to be healed.

I know what I am talking about, having also been intensively involved in starting a process of elaborating a Czech-Austrian common Report of Historians that is presently promoted intensively in order to reach out to large parts of the public and to break up stereotypes that have been weighing heavily on Czech-Austrian relations for decades. The intention was to educate a larger public about the complexity of historical facts and developments, that there is never only one side to blame and that both neighbouring countries are now, both, members of the European Union and thus in an entirely new position to reconcile opposing views and by initiating concrete action in order to create a sound factual basis for a co-operative future.

Exactly here lies the main potential impact of this Summary Report. It forms a differentiated but still sufficiently communicable picture: In the second part of this synthetic report, 600 years of family history, between 1200 and 1805, have been summarized in a concise manner to be followed by a more extensive exposure of the history of the Liechtensteins in Czech lands in the $19^{\text {th }}$ century. The $20^{\text {th }}$ century with its continuities and discontinuities and the deep crises in the relations between Czechoslovakia and the Liechtensteins, as family and as principality, receives, in this summary, a more extensive 
attention, including a presentation of the four princes, who reigned the principality during this century, in their respective historical context.

Its main Chapter III, which is one of the most important parts of the publication, starts with the core issue of places of memory and attempts to form a historical image of the Liechtensteins. This is a very skilful way of covering the wealth as well as the problematic developments in the Liechtenstein-Czech relations. This approach has the potential to open the eyes of many readers who, up to now, only had a superficial view on these relations. Places of memory are concrete and have been used or misused in order to, positively or negatively, influence the historical image of the Liechtensteins in the eyes of Czechs, Liechtensteinians but also of the outside world.

The next topic in the Summary report leads us straight into the impact that the Liechtensteins had on the arts, architecture and culture in general in the Czech and Moravian lands. This chapter seems to me particularly important for the Czech public, particularly also for young people. They are (and this was my observation during six years serving in this country), they are proud of their national heritage forming part of their national identity, but many are not yet fully aware, who contributed to it in the past and how relevant this contribution is for the present and future. But on the other hand, I really feel that, as opposed to even the more recent past, more and more young people are increasingly aware of their cultural heritage and of the families, who contributed to it. The younger generations seem more ready than ever before to accept these families as a living link to this heritage. And this seems also true for the Liechtensteins, particularly here in Moravia, where this heritage is most visible.

All that may also apply to visitors from other European and overseas countries that may be fascinated by the cultural wealth of Czech and Moravian lands but do not know enough about its origins.

The third substantial part of this publication deals with the events of the $20^{\text {th }}$ century, the expropriations during the first Republic's land reform and the placing under national administration and declaration of confiscation on the basis of the presidential decrees Nr. 5 and 12 in 1945. These decisive and potentially divisive episodes, too, have been dealt with in a careful and differentiated way that may well serve to better understand the facts as well as the motives of the decision makers on both sides in their respective historical context. The presentation of these episodes is carried out in an impressively careful manner full of respect for the parties involved.

Indeed, these two publications have, therefore, the potential to make a decisive contribution to re-defining the entire historical context of the relations between the Czech Republic and the Liechtensteins. How important this historical context has become is shown by the political and constitutional developments of the past hundred years. Only 100 years ago serious historians like Joseph Pekař and Karel Kadlec qualified the expropriation of the reigning prince of Liechtenstein and his family in the Czech lands as acts of retribution if not revenge, but in any case as punitive measures against this family for the "crimes" committed by Karl I. of Liechtenstein 300 years before in the context of the battle of the white mountain and in relation to the land acquired by the Prince, at least seen from the hind side, in a manner of doubtful legality. Such narrative, then, 
was surely considered publicly and politically widely accepted and even natural within the fledgling Czechoslovak nation state fighting for a historical identity and trying to establish a new social order abolishing extensively large land ownership inherited from the Austro-Hungarian monarchy. Today much of this narrative can at best only be understood if placed into the specific situation of a nation looking for a new identity after 350 years under Habsburg rule.

But what is the difference made by the findings of the Commission of Historians and their synthetic account given in the summary report?

As far as for instance Karl I is concerned, we can, today, base our considerations in critically viewing such historical narrative on extensive research. Extensive research on this complex personality was carried out and published particularly by Tomas Knoz and Thomas Winkelbauer and, as mentioned before, by Arthur Stögmann and Jiři Brňovják. They have researched and published intensively and extensively, objectively and in detail on the figure of Karl Liechtenstein, for instance his role in serving the Kaiser by organizing the punishment of persons found responsible for the uprising by the Bohemian "Stände", his attempts to increase his land holdings by making use of his privileged position, his highly problematic actions in relation with his participation in the mint consortium (Prager Münzenkosortium) etc. All these episodes were contributing to a narrative qualifying Karl I. simply and without further qualification as brutal, reckless and opportunistic thus facilitating the misuse of such stereotypes for political or legal purposes or for somehow problematic ways of historical nation branding considered necessary for nation-building at the time after the end of the Habsburg monarchy.

Today the members of the commission of historians and an impressive number of other contributors have developed such a rich picture of the relationship between today's Czech Republic and the Liechtenstein family as important part of their common cultural, economic, social and political heritage that we may consider this research, published to a large extent but in any event fully reflected in the 8 volumes of the Liechtenstein-Czech commission of historian's reports as a real and most valuable treasure. I would dare to say that this treasure now constitutes even an important part of the Czech national heritage that may be contributing to a new and sustainable national identity of the Czech Republic based on a solid acceptance of all aspects of its national history. I think the next generations of Czechs have a right that their national identity does not need distortive narratives in order for the Czech Republic to be regarded as a historically und culturally wealthy nation that has regained its position as living centre of Europe that it always was.

After the two periods of the $20^{\text {th }}$ century during which the Liechtenstein property in Czechoslovakia was affected first by the land reform and later by national administration and declaring of confiscation, I would dare to say the following: The 8 volume report of the Commission of Historians, the book published in honour of Tomas Winkelbauer and all the other publications listed in more than 40 pages of sources and literature in the Commission's report provide an entirely new and different basis of knowledge. Any judgement on the role and impact of the Liechtensteins in the Czech and Moravian lands can, therefore, be built today on a different and by far more elaborate basis than at any time in the past. 
I do not know to what extent you had time and opportunity to observe the legal claims that are presently dealt with by a number of district and regional courts that have been decided upon by the Supreme Court and are now in front of the Constitutional Court here in Brno. As far as I can see, these court cases have at least one positive aspect. They force the parties to the legal disputes, i.e. the different representatives of the Czech state on the one hand and the representatives of the heirs of prince Franz Joseph II., to make use of the rich knowledge acquired and assembled by the historians dealing with the Liechtensteins in the Czech lands. In arguing the cases, much of the historical stereotypical arguments are surfacing again. But today, they face an increasingly informed public or at least a public that senses that legal controversy on issues of property alone cannot be the right way to find a solution for this very special case that reflects the very specific character of the relations between the today's Czech Republic and the Liechtensteins.

I would be totally misled, if I would not see a certain development in the minds not only of the participants in the legal disputes but also of the observers. We may even notice that something of the research that has been done is now trickling down into not only a group of persons with qualified knowledge but even to the large public. Persons who deal with the media recognize that an increasing number of journalists take a much more informed stance on the issue of the Liechtensteins including the expropriation. than only a few years ago. Recently a poll has been made that shows that already a majority among Czechs consider the case of the Liechtensteins as opposed to most other cases affected by the presidential decrees, as a special case, requiring a special solution. Among the young people that number even amounts to already about two thirds.

There is no doubt that even the broad public not only here in Moravia senses that the relationship with the Liechtensteins requires a more lasting reconciliatory solution rather than endless disputes before Czech and international Courts.

Who knows, probably the time is near, when more and more responsible people and finally politicians start to think that the Liechtensteins are probably the one case that, if properly solved in the interest of all, may help to contribute to a new Czech identity that does not have to sweep certain issues under the carpet that still create uneasiness when trying to look back proudly to the Czech history constituting the basis of such identity.

I have been actively involved in restitution and compensation in Austria for injustices done to Nazi victims not only during the war but particularly also after the war. I am a witness of the importance of getting rid of some undigested issues of the past weighing heavily on the development of a really true and honest national pride.

I think that a solution to the, really under most aspects, special case of the Liechtensteins that would duly take into account the findings of the commission of historians could be achieved in a way acceptable to all sides. In my personal view such a solution should be be based on the wealth of newly acquired knowledge about 800 years of common history, taking due account of the positive and of the negative aspects. It sould be a political solution in the true sense and should serve a common sustainable future. It could even become a very important structural element of the common future of the Czech Republic and Liechtenstein in a prosperous Europe.

I think that such a solution is timely: 
When becoming a new Republic after 350 years of foreign rule, the Liechtensteins and the application of the land reform upon them represented a core issue for the new nation to reorganize its society.

In 1945 the application of the presidential decrees also to the reigning prince of Liechtenstein and other Liechtenstein citizens was, influenced by a spirit of revolution and high emotionality, considered to be an act of retribution for the sufferings of the ethnic Czechs and Slovaks during World War II. These measures were taken against persons considered "German", thus bearing collective responsibility for Nazi oppression and crimes and against persons considered unduly wealthy. More rationally, they were seen a necessary part of the reconstruction of the Czechoslovak society. Legally and ethically, the decrees, in this case, were obviously applied to the wrong persons since the reigning prince of a foreign sovereign and neutral country and other, including Jewish, Liechtenstein citizens could hardly have been held responsible for the Nazi opression. The actions against the Liechtensteins were, after all,already an expression of the quickly growing power of the communist influence in a Czechoslovakia that was just freed from the joke of Nazi rule and about to quickly falling victim to the Stalinist oppression.

But today, the environment is a totally different one. The Czech Republic is part of the European Union, one of the most prosperous countries in Europe and in the world, standing fully on its own feet. This changed situation also enables Czech society to overcome the last stumbling stones to basing the prosperity of the country on a solid consciousness of a rich history. Today, the Republic is in a position to solve the last open issues from the past that would allow identifying itself with all the achievements of the past of the Czech and Moravian lands and in fully making use of them.

We, members of the Commission of historians, are conscious that historical research, in order to develop its full impact, is not supposed to be hidden in publications only read by other historical experts. No, the real value of this treasure consists in making the commission's findings accessible to the large public inside and outside of the Czech Republic and of course also within the Principality f Liechtenstein. These findings are also of high concern to an often misled public in Germany, Austria and, in other European countries, particularly the countries of Central Europe. These findings should become part of the curricula of secondary schools, they should educate a new learned journalism, a journalism of knowledge that is strong enough to resist the superficial and topical digital information transferred in real time by communication inciting also today's increasingly populistic politicians to succumb to stereotypisation and polarisation. This treasure of historical findings is part of the very European identity of both nations, the Czech Republic and Liechtenstein, situated between the banks of the river Rhine and the banks of the Morava.

I am, therefore, convinced that the Commission, together with the Governments supporting it, should become even more inventive in making its findings available to a large public through modern ways of communication and networking. We are able to do it and he fact that the commission has a website is an excellent basis for such communication. We have a job to do with the help of all of you. We appreciate the performance of all the historians, art historians and experts contributing directly or indirectly to the 
8 volumes of the report of the Commission of Historians and to the book honouring with Prof. Thomas Winkelbauer one of its outstanding members. The last volume of the Commission's report, the Summary Report, should serve as the best available tool to help us penetrating a larger, non-expert public. Its English version should also serve as an excellent basis to bring the work of the Commission to the attention of an international public. As a non-contributor, I feel well suited to thank all those, who contributed to this most valuable publication.

Thank you for your attention.

(Intervention by Ferdinand Trauttmansdorff on November 20, 2019, Brno)

\section{Resumé}

\section{Dvě publikace, jedno poselství}

Bývalý velvyslanec Rakouské republiky v České republice Ferdinand Trauttmannsdorff ve své přednášce, pronesené na půdě Filozofické fakulty Masarykovy univerzity v Brně v rámci akce „Dny Lichtenštejnské historie v České republice“ představil dva projekty Česko-lichtenštejnské komise historiků. V prvním případě jde o vydání publikace „Fürstenhaus Liechtenstein - Böhmische Länder - Fürstentum Liechtenstein. Ad honorem Thomas Winkelbauer“, jež byla uveřejněna v rámci časopisu Studia historica Brunensia. Autoři z okruhu Česko-lichtenštejnské komise historiků v ní uveřejnili celou řadu statí, které se zabývaly různými aspekty dějin rodu Lichtenštejnů a jejich vazeb na české země, dějin Knížeczví Lichtenštejnsko, ale i některými obecněji uchopenými tématy z evropských dějin. Druhým představeným tématem bylo vydání anglické jazykové mutace takzvané „souhrnné zprávy Česko-lichtenštejnské komise historiků“ komise, a sice pod názvem „Czech-Liechtenstein Relations. Past and Present“. Autor přednášky přitom obzvláště zdůraznil pasáže věnované místům lichtenštejnské paměti a konstruování různých historických stereotypů, typických pro česko-lichtenštejnské vztahy v dlouhém trvání. Zároveň zdůraznil některé možnosti, které by podle jeho názoru mohlo zlepšení česko-lichtenštejnských vztahů a vyřešení otázek považovaných za otevřené v budoucnosti přinést nejen oběma zúčastněným zemím, ale i Evropě jako celku. 